УДК 602.9:611.018: 612.34, DOI 10.31210/visnyk2018.02.21

(C) 2018

Ковпак В. В., кандидат ветеринарних наук, Ковпак O. C., аспірант

(науковий керівник - доктор ветеринарних наук А. Й. Мазуркевич)

Національний університет біоресурсів і природокористування України

\title{
ПОРІВНЯННЯ РІЗНИХ МЕТОДІВ ВИДІЛЕННЯ СТОВБУРОВИХ КЛІТИН З ПІДШЛУНКОВОЇ ЗАЛОЗИ ЩУРА
}

\section{Рецензент - доктор ветеринарних наук, професор М. О. Малюк}

У статті наведено результати порівняння різних методів дезагрегащії підшлункової залози щура задля отримання первинної культури. Нами порівняно 4 методи дезагрегації: обробка первинної тканини колагеназою, тепла та холодна трипсинізації, а також модифікований метод експланту. Для аналізу результатів здійснювали підрахунок кількості клітин після утворення моношару в одній із чашок. Аналізуючи результати дослідження, можна стверджувати, що оптимальним методом отримання культури стовбурових клітин підчлункової залози щура є модифікований метод експланту, оскільки кількість клітин на 14-ту добу культивування становила

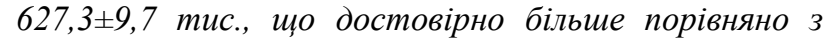
іншими досліджуваними методами.

Ключові слова: стовбурові клітини, культура клітин, підшлункова залоза, дезагрегачія тканин, иуурі.

Постановка проблеми. У лікуванні цукрового діабету особливо актуальним $є$ оптимізація отримання культури клітин підшлункової залози 3 метою їх терапевтичного використання. Проте питання виділення адгезивних, здатних до поділу клітин, 3 даної залози досліджено недостатньо. Це, у свою чергу, зумовлює необхідність розробки та порівняння різних методів виділення стовбурових клітин 3 підшлункової залози задля виявлення оптимального.

Аналіз основних досліджень і публікацій, у яких започатковано розв'язання проблеми. Питання щодо шляхів регенерації підшлункової залози досі відкрите. Більшість науковців схиляється до думки, що цю функцію виконує протоковий епітелій, клітини якого, як вважають, є «факультативними стовбуровими клітинами» [24]. Проте деякі дослідники вказують на наявність мультипотентних клітин-попередниць у самій підшлунковій залозі $[5,8]$. Деякі дослідники вказують і на здатність $\beta$-клітин до поділу [7].

Отже, можна стверджувати, що первинна тканина підшлункової залози гетерогенна за своїм клітинним складом. 3 огляду на це, необхідність оптимізації виділення клітин, здатних до пролі- ферації, 3 підшлункової залози видається ще більш актуальною, адже від методу отримання первинної культури залежить іiі подальший клітинний склад та біологічні властивості.

Мета дослідження: порівняти різні методи дезагрегації підшлункової залози щура задля отримання первинної культури.

Завдання: отримати підшлункову залозу у щурів; дослідити різні методи дезагрегації тканини підшлункової залози.

Матеріали і методи: для отримання підшлункової залози (ПЗ) використовували 12-денних щуренят (після їх попередньої евтаназіі).

Доступ до підшлункової залози у тварин здійснювали через розріз черевної стінки від мечоподібного відростку грудної кістки до тазового зрощення шляхом пошарового розтинання шкіри та м'язів черевної стінки по білій лінії. Попередньо шкіру та шерсть тварин обробляли $70 \%$ етанолом задля попередження потрапляння шерсті у зразки.

Підшлункову залозу обережно відпрепаровували та виймали з черевної порожнини у стерильну чашку Петрі, де іiі тричі промивали фосфатно-буферним розчином (ФБР) (Sigma, США). Після чого відділяли залозисту частину і подрібнювали ножицями на шматочки розміром 1-2 мм³. Подрібнену тканину масою 10 мг вносили у пробірки для визначення оптимального методу дезагрегації.

Ми порівнювали 4 методи дезагрегації тканини підшлункової залози:

Обробка колагеназою. В пробірку до шматочків тканини у DMEM (середовище Ігла модифіковане Дюльбеко) (Sigma, США) додавали

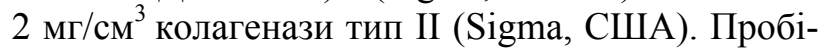
рки поміщали у $\mathrm{CO}_{2}$ інкубатор на 1 годину. Після закінчення визначеного часу їх піддавали центрифугуванню протягом 20 хв. за відцентрової сили 300 g. Зливали надосадову рідину, а до осаду клітин додавали поживне середовище, яке складалося з 80 \% DMEM, 20 \% фетальної сиро-

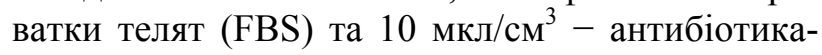




\section{ВЕТЕРИНАРНА МЕДИЦИНА}

антимікотика, розпіпетовували, переносили в чашки Петрі та ставили на культивування;

Метод теплої трипсинізації. Шматочки тканини переносили за допомогою піпетки до скляного стакану, у який вносили $100 \mathrm{~cm}^{3}$ 0,25\%-го розчину трипсину (Sigma, США), підігрітого до температури $37{ }^{0} \mathrm{C}$. У стакан поміщали магнітний маячок та здійснювали перемішування на магнітній мішалці зі швидкістю 100 об./хв. протягом 30 хвилин. Через 30 хвилин суспензію клітин відбирали у центрифужні пробірки та інактивували фермент додаванням сироватки. У стакан до шматочків тканини додавали нову порцію ферменту і повторювали дезагрегацію до максимального виснаження тканини. Суспензію клітин осаджували центрифугуванням при $500 \mathrm{~g}$ протягом 5 хвилин. Осад клітин ресуспендували у культуральному середовищі (DMEM - 80 \%, FBS -

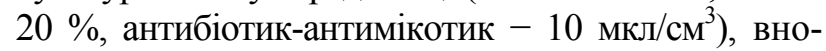
сили в культуральний посуд та ставили на культивування.

Метод холодної трипсинізації. У пробірку до шматочків тканини додавали $0,25 \%$-ий розчин трипсину (Sigma, США), приготовленому на культуральному середовищі 3 розрахунку $10 \mathrm{~cm}^{3} / \Gamma$ тканини та переносили на 6-18 годин у холодильник ( $\left.4{ }^{0} \mathrm{C}\right)$. Після закінчення часу експозиції за допомогою шприца відбирали фермент (залишаючи 1-2 $\mathrm{cm}^{3}$ ), пробірки переносили у термостат на 20 хвилин при t $37{ }^{0} \mathrm{C}$. Потім у пробірку додавали тепле середовище 3 розрахунку $1 \mathrm{~cm}^{3}$ на кожні 100 мг тканини та за допомогою піпетки дезагрегували тканину до утворення однорідної суспензії клітин. Суспензію клітин осаджували центрифугуванням при $500 \mathrm{~g}$ протягом 5 хвилин. Осад клітин ресуспендували у культуральному середовищі (DMEM - 80\%, FBS - $20 \%$, антибіотик-антимікотик - 10 мкл/ $\left.\mathrm{cm}^{3}\right)$, вносили в культуральний посуд та ставили на культивування.

Модифікований метод експланту. Шматочки тканини поміщали до культурального посуду та заливали культуральним середовищем, яке скла- далося з 80 \% DMEM, 20 \% фетальної сироватки

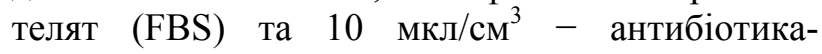
антимікотика та ставили на культивування.

Для аналізу результатів здійснювали підрахунок кількості клітин після утворення моношару у одній із чашок. Пасажування клітин здійснювали у співвідношенні 1:2 за стандартною методикою $[1,6]$.

Результати досліджень щодо визначення оптимального методу отримання культури стовбурових клітин з підшлункової залози щура наведені у таблиці та рисунку.

На третю добу культивування за використання перших трьох методів дезагрегації у чашках Петрі виявляли появу поодиноких адгезованих клітин. У разі використання 4 методу обробки тканин П3 появу адгезованих клітин спостерігали на 4-5-ту добу після висівання. Проте варто зазначити, що інтенсивність проліферації клітин була найвищою за використання методу експланту.

Найменш ефективним 3 досліджуваних методів був метод, який передбачав обробку тканин підшлункової залози колагеназою (рис. 1, а). Кількість клітин на 14-ту добу культивування була у 2,9 разів меншою у порівнянні з контролем та становила $216,3 \pm 12,4$ тис.

За використання методу теплої трипсинізації кількість клітин на 14-ту добу культивування була у 1,6 разів меншою, ніж у контролі та становила $385,0 \pm 16,2$ тис. (рис. 1, в).

Найкращий ефект у разі використання ферментної обробки тканин підшлункової залози було отримано за використання холодної трипсинізації: кількість клітин у моношарі на 14-ту добу культивування за використання даного методу становила $475,0 \pm 27,9$ тис. (рис. 1, б), проте була у 1,3 разів нижчою у порівнянні з контролем.

Аналізуючи результати дослідження, представлених у таблиці 1, можна стверджувати, що оптимальним методом отримання культури стовбурових клітин з підшлункової залози щура $\epsilon$ модифікований метод експланту.

Кількість клітин у моночарі залежно від методу обробки тканин підилункової залози (М士m, n=3)

\begin{tabular}{|c|c|c|c|c|}
\hline \multirow[b]{2}{*}{ Показник } & \multicolumn{4}{|c|}{ Метод обробки } \\
\hline & 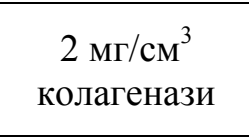 & $\begin{array}{l}\text { Тепла трипсинізація } \\
(0,25 \% \text {-ий трипсин) }\end{array}$ & $\begin{array}{c}\text { Холодна трипсині- } \\
\text { зація }(0,25 \% \text {-ий } \\
\text { трипсин })\end{array}$ & $\begin{array}{c}\text { Метод } \\
\text { експланту } \\
\text { (контроль) }\end{array}$ \\
\hline № методу & 1 & 2 & 3 & 4 \\
\hline $\begin{array}{c}\text { К-ть клітин, тис. } \\
\text { (14-та доба } \\
\text { культивування) }\end{array}$ & $216,3 \pm 12,4 * * *$ & $385,0 \pm 16,2 * * *$ & $475,0 \pm 27,9 * *$ & $627,3 \pm 9,7$ \\
\hline
\end{tabular}

Примітка: $* * * \mathrm{P}<0,001 ; * * \mathrm{P}<0,01 ; * \mathrm{P}<0,05$ порівняно $з$ контролем 

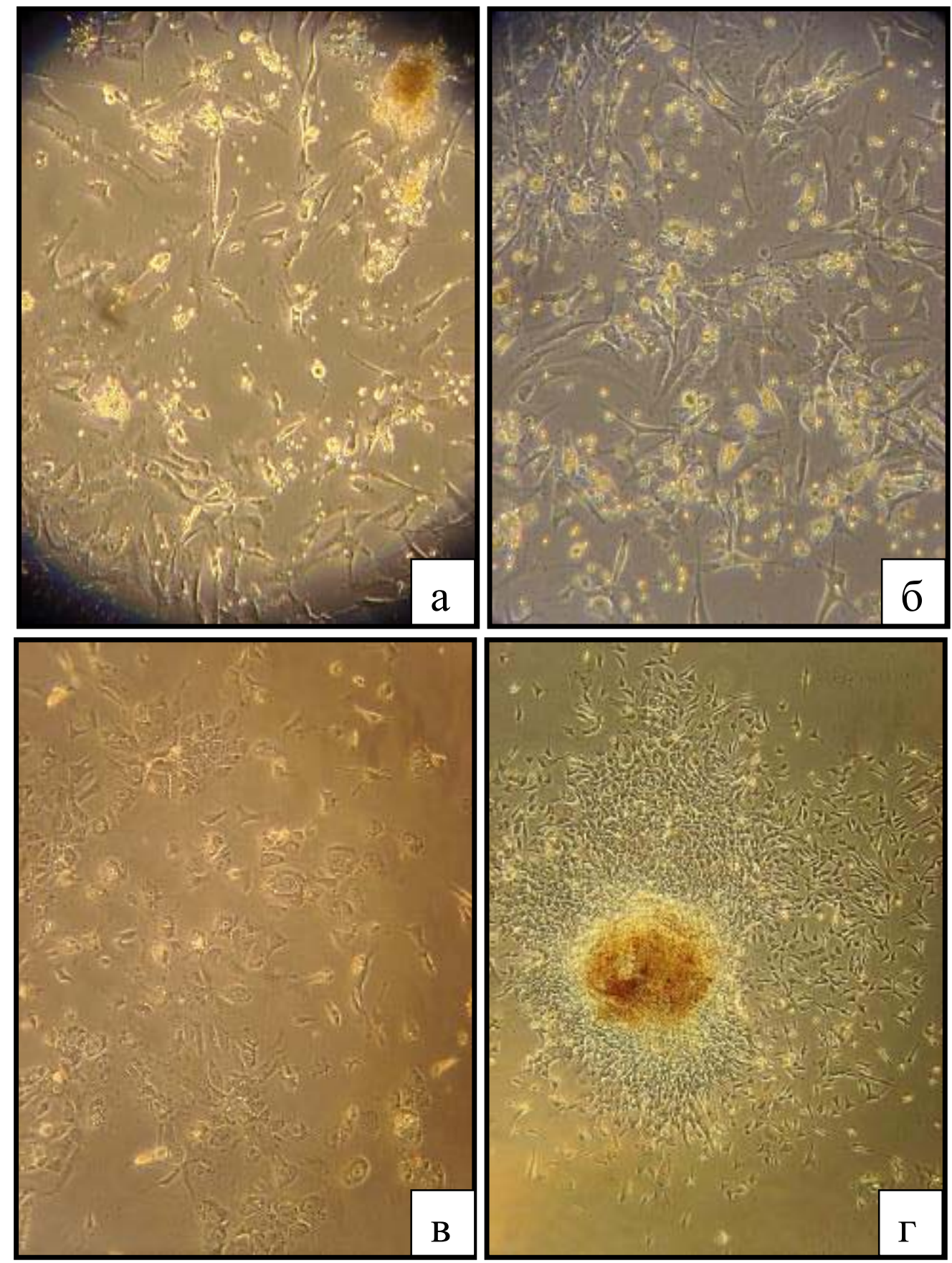

Рис. 1. Мікрофотографї̈ культур клітин, отриманих з підшлункової залози шурів, 7-ма доба культивування (0-й пасаж):

а) метод 1; б) метод 3; в) метод 2; г) метод 4. Нативні препарати. 3б. на рис. а, б, в- $3320,2-450$

Кількість клітин у моношарі на 14-ту добу культивування становила $627,3 \pm 9,7$ тис., що достовірно більше порівняно з іншими досліджуваними методами. Отримані дані можна пояснити тим, що ацинарні клітини екзокринного відділу підшлункової залози містять у своєму складі ферменти, які внаслідок руйнування клітинної стінки вивільняються у поживне середовище та пошкоджують інші клітини, які втрачають здатність до адгезії та ділення.
Дану гіпотезу можна додатково підтвердити, порівнявши ефективність отримання культури клітин 3 підшлункової залози шляхом холодної та теплої трипсинізації, які відрізняються активністю ферментів, що діють на первинну тканину: за використання методу холодної трипсинізації, у якому фермент менш активний порівняно $з$ теплою трипсинізацією, ми виявили більшу кількість клітин у моношарі по завершенню дослідження. 


\section{ВЕТЕРИНАРНА МЕДИЦИНА}

Висновок. Використання методу експланту $\epsilon$ оптимальним для отримання культури стовбурових клітин 3 підшлункової залози щурів. Ферментивна та механічна дезагрегації призводять

\section{БІБЛІОГРАФІЯ}

1. Мазуркевич А. Й., Ковпак В.В., Данілов $B . Б$. Клітинні технології у ветеринарній медицині // Навчальний посібник. - К. : КОМПРИНТ, 2014. $-132 \mathrm{c}$.

2. The pancreatic ductal epithelium serves as a potential pool of progenitor cells. Pediatr. Diabetes / Bonner-Weir S., Toschi E., Inada A., Reitz P., Fonseca S. Y., Aye T., Sharma A. - 2004. - Vol. 5, suppl. 2. - P. 16-22.

3. Bonner-Weir S., Taneja M., Weir G. In vitro cultivation of human islets from expanded ductal tissue. - Proc. Nat. Acad. Scien. USA. - 2000. №97. - P. 7999-8004.

4. Would pancreas duct-epithelium-derived stem/progenitor cells enhance islet allograft survival by means of islets recruitment and tolerance induction in Edmonton protocol era? Med. Hypotheses / Chen B., Wang L., Hu S., Zhou L., Wang R., Wachtel M. S., Frezza E. E. - 2008. Vol. 3, №70. - P. 661-664.

\section{ANNOTATION}

Kovpak V. V., Kovpak O. S. Comparison of different methods of selection of stem cells from the pancreas to getting a culture.

In the treatment of diabetes mellitus is particularly relevant to study the culture of cells derived from pancreatic tissue. However, the question of selected cells which could to adhesive and david, from this gland, is not studies enough. This, in turn, necessitates the development and comparison of various methods for the selection of stem cells from the pancreas in order to identify the optimal. That is why the purpose of our study was to compare different methods of disaggregation of the pancreas of the rat to obtain primary culture.

To determine the optimal method for obtaining the culture of stem cells of the pancreas of the rat, we compared four methods treatment of tissue: collagenase treatment, warm trypsinization method, cold trypsinization method, modified explant method. The analysis of the results, was counting the number of cells, which carried out after formation a monolayer in one of the cups. On the third day of cultivation in Petri dishes revealed the appearance of single adhesive cells at use of the first three methods of disaggregation.

For using the fourth method of disaggregation pancreatic tissue, was noted the appearance of adherent до руйнування ацинарних клітин, вивільнення їх ферментів, що викликає загибель значної кількості стовбурових клітин, які складають основу клітин культури підшлункової залози.

5. Gopurappilly R., Bhat $V$., Bhonde $R$. Pancreatic tissue resident mesenchymal stromal cell (MSC)-like cells as a source of in vitro islet neogenesis. J. Cell Biochem. - 2013. -Vol. 10, №114. - P. 2240-2247.

6. Ian Freshney $R$. Culture of animal cells: a manual of basic technique. [ $5^{\text {th }}$ ed.]. USA : John Wiley \& Sons, 2005. - 642 p.

7. Juhl K., Bonner-Weir Susan, Sharma Arun. Regenerating pancreatic $\beta$-cells: Plasticity of adult pancreatic cells and the feasibility of in vivo neogenesis. Curr. Opin. Organ Transplant. 2010. - Feb. -Vol. 1, №15. - P. 79-85.

8. Stanger B. Z., Tanaka A. J., Melton D. A. Organ size is limited by the number of embryonic progenitor cells in the pancreas but not the liver. Nature. - 2007. - №445. - P. 886-891.

cells on the fourth-fifth day after sowing. However, it should be noted that the proliferation of cells was the highest in the use of the explant method. The least effective of the investigated methods was the treatment of pancreatic tissue $2 \mathrm{mg} / \mathrm{cm}^{3}$ collagenase. The number of cells in the 14th day of cultivation was 2.9 times lower compared to control (without the use of enzymes) and amounted to $216.3 \pm 12.4$ thousand. With the use of the warm trypsinization method, the number of cells per 14th days of cultivation was 1.6 times smaller than that of the control and amounted to $385.0 \pm 16.2$ thousand. The best effect of using the enzymatic processing of the pancreas was obtained using the cold trypsinization method. The number of cells per 14th days of cultivation when using this method was $475.0 \pm 27.9$ thousand and was in 1.3 times lower compared to control.

Analyzing the results of the study, it can be argued that the optimal method for obtaining the culture of stem cells of the pancreas of the rat is the modified method of explant. The number of cells per $14^{\text {th }}$ days of cultivation was $627.3 \pm 9.7$ thousand. This is significantly more compared with other investigated methods.

Key words: stem cells, cell culture, pancreas, disaggregation, rats. 